\title{
Energy production and use in Dutch agriculture
}

\author{
W. A. Dekkers ${ }^{1}$, J. M. Lange ${ }^{2}$ and C. T. de Wit ${ }^{1},^{3}$ \\ ${ }^{1}$ Department of Theoretical Production Ecology, Agricultural University, Wageningen \\ 2 Institute of Agricultural Engineering and Rationalization (ILR), Wageningen \\ ${ }^{3}$ Institute of Biological and Chemical Research on Field Crops and Herbage (IBS), \\ Wageningen
}

Accepted: 30 April 1974

\section{Summary}

Energy relationschips in the agriculture of one of the most densely populated areas of the world, the Netherlands, are described. The Netherlands appear selfsupporting in food energy. However, if one takes account of energy consumption in horticulture, the direct and indirect fossil energy cost exceeds the food energy produced in agriculture. An input-output analysis to estimate the indirect energy is applied on Japanese data. It appears that in Japanese agriculture for every unit energy used directly, two units are used indirectly.

Energy relationships are different for the main agricultural sectors. In the primary production sector more energy is produced than consumed $(9: 1)$, while in the secondary production sector and in the horticulture the oppositie holds $(1: 7)$. The energy input of the secondary production sector, however, is mainly of plant origin.

Energy balances of an arable farm at present and around 1800 are given to show in more detail in which way food energy is and was produced. Possible ways to diminish the fossil energy input of the modern farm are discussed.

\section{Introduction}

Agriculture is the human activity to collect solar energy by conversion into edible chemical energy by means of plants and animals. In recent years, it has been gradually realized that considerable amounts of fossil energy are also used in the process. This expenditure is so great that agriculture could be defined as the activity that converts fossil energy in edible chemical energy by means of plants and animals (de Wit \& Nooy, 1973).

The Netherlands is the country with the highest primary production per unit surface, and therefore it is of particular interest to analyse its energy interrelations. For this purpose all energy production and consumption is expressed in $10^{6}$ or $10^{12} \mathrm{kcal} / \mathrm{year}$. This simplification is even greater than expressing everything in money. Oil is a form of energy different from electricity, and both are again different from grain, milk, meat, or human labour. Adding up energy from such completely different sources is rather like adding up the weights of all red objects in town. However, with some care, the data may be meaningfully interpreted as totals.

In the present paper, attention is first paid to the level of primary and secondary production and consumption in the Netherlands. Then the direct energy consumption in the form of oil, gas and electricity is considered. Apart from this, some attention is paid to 
determining the so-called indirect consumption of energy. This is the energy needed for fertilizers, herbicides, tractors, land improvement, etc. The reader is warned that this level of indirect energy consumption can only be very roughly estimated at this stage. The data are used to consider the three main sectors of Dutch agriculture in more detail: primary production, secondary production and horticulture.

The energy relations in the Southwestern clay district are considered in the presentday situation and around the year 1800 to illustrate development in arable cropping.

\section{Food energy production and consumption}

The FAO published (Anon., 1971) food balance sheets of every country for the year 1964-1965, and these, rather than more recent data, are used as a basis in analysing the food energy interrelations in the Netherlands. At that time the Netherlands had a surface of 2568000 ha, of which 1337000 ha was under grassland, 800000 ha under arable land, 128000 ha under horticulture, of which 6000 ha under glass. The total population was about 12.5 million.

The primary source of energy is the sun and the land under cultivation receives about $14000 \times 10^{12} \mathrm{kcal} /$ year in the form of radiation. This is the grand total of the whole year, including infrared radiation. Photosynthetic active radiation is about half this amount. As illustrated in Fig. 1, this energy flow yields $50 \times 10^{12} \mathrm{kcal} /$ year as grass and green fodder and $12 \times 10^{12} \mathrm{kcal} /$ year as marketable arable products exclusive of $8 \times 10^{12} \mathrm{kcal} /$ year as straw and tops. Horticulture yields another $2 \times 10^{12} \mathrm{kcal} / \mathrm{year}$, exclusive of bulbs, roses and other flowers which are considered inedible.

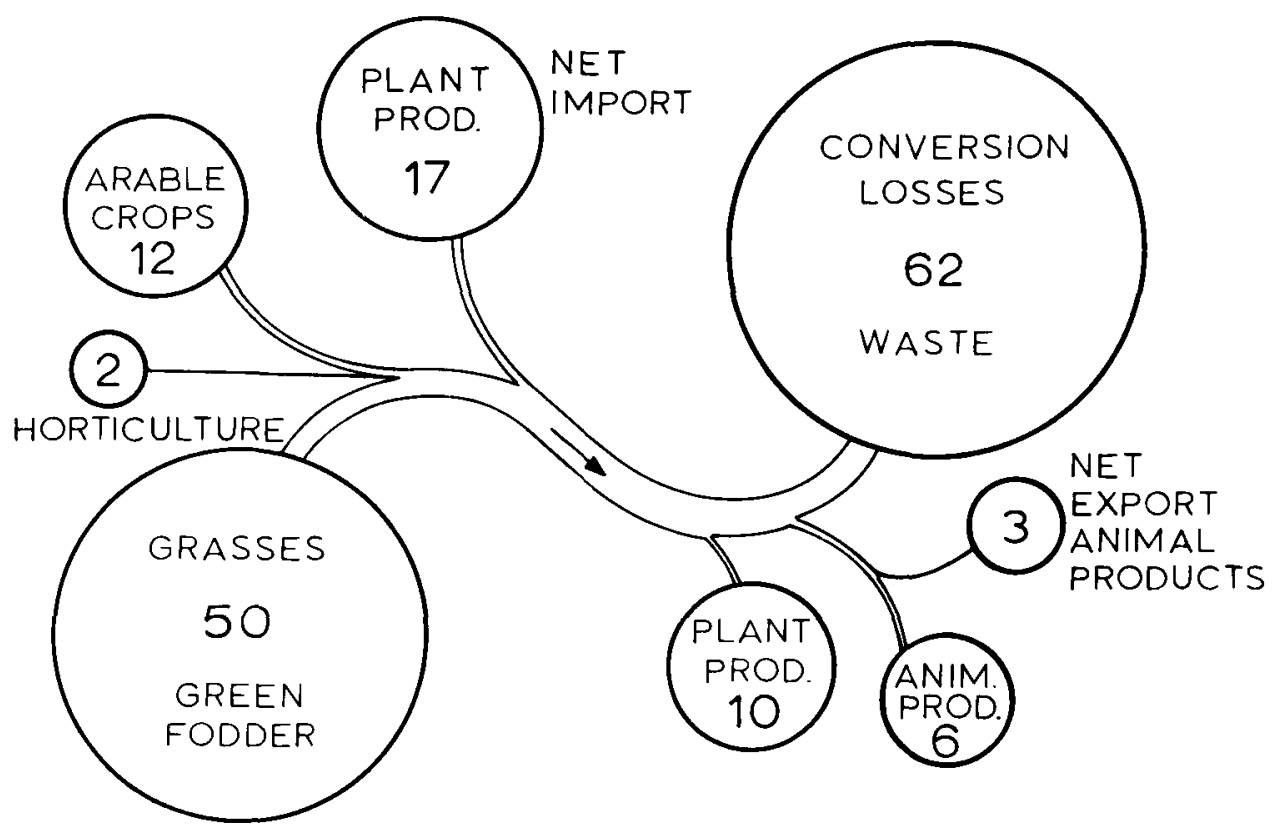

Fig. 1. Energy flow in Dutch agriculture in 1965 (in $10^{12} \mathrm{kcal} / \mathrm{year}$ ). 
A part of this primary production is exported, but more is imported, leading to a net import of primary produce of $17 \times 10^{12} \mathrm{kcal} /$ year, including the import of animal food other than grain and pulses not accounted for by the FAO balance sheets. Only $10 \times 10^{12} \mathrm{kcal} /$ year of the total available primary products of $81 \times 10^{12} \mathrm{kcal} / \mathrm{year}$ are used directly in human consumption in the country. The remaining is converted into meat, milk and eggs with the consequence that the greater part, $62 \times 10^{12} \mathrm{kcal} /$ year, is lost by conversion and in waste. The resulting produce is about $9 \times 10^{12} \mathrm{kcal} / \mathrm{year}$ of which $6 \times 10^{12} \mathrm{kcal} /$ year are consumed in the country and the remaining $3 \times 10^{12}$ $\mathrm{kcal} / \mathrm{year}$ are exported as meat, milk products and eggs. About $20 \times 10^{12} \mathrm{kcal} / \mathrm{year}$ of primary products are required in producing this export. Thus, since only $17 \times 10^{12}$ $\mathrm{kcal} /$ year are imported as agricultural produce, the Netherlands appear to be selfsupporting - a situation perhaps unexpected in one of the most densely populated areas of the world. This is the more so because the potential primary production in the Netherlands (de Wit, 1972) is still roughly twice the present level.

In the next sections it is calculated and estimated that the fossil energy input in direct and indirect form is about $31 \times 10^{12} \mathrm{kcal} /$ year, which is more than the net production of about $20 \times 10^{12} \mathrm{kcal} /$ year in all three sectors. An overall conclusion is therefore that more energy is used in the form of fossil energy than produced in the form of edible energy. This leads to the definition of agriculture being the activity of converting fossil energy into edible energy. However, it will be shown that such an overall view gives a considerable distorted picture of the actual situation.

\section{The direct use of fossil energy}

The direct use of fossil energy in Dutch agriculture is needed in the propulsion of tractors and agricultural machinery, in heating of buildings and greenhouses and in regulating the water level in the 'polders'. The fuel required in heating of greenhouses is exactly known, because the producers receive tax reimbursements on their fuel use for this purpose (Anon., 1966b). Lange (1973) collected detailed data on the actual use of tractors and the consumption of fuel per hour. Thus, with the statistical information on the number of tractors of various types and the self-propelling agricultural machinery, the fuel consumption for this purpose can be calculated. Some provincial electricity companies provide data on the use of electricity by farmers. Substracting domestic use, about $1 / 24$ th of the total electricity production is used at the farm. The amount of energy used in pumping stations is also known, but the oil and natural gas use for this purpose is not known, although probably small.

The direct energy use at the farm is considered. The energy cost to produce this energy is not taken into account here, but in the next section. The energy cost of transport, drying and processing outside the farm are neither considered.

The direct use of fossil energy is summarized in Table 1 for the year 1965, the same year on which the FAO food balance sheets are available. The total use in Dutch agriculture amounts to $20 \times 10^{12} \mathrm{kcal} /$ year. The greater part is used in horticulture to heat greenhouses. The remaining part, about $5 \times 10^{12} \mathrm{kcal} / \mathrm{year}$, is the direct energy input of the other two sectors. The latter compares favourably with the energy output in the form of plant and animal products. However, taking into account the indirect energy use and the further separation in sectors will change this picture again.

It is temping to compare the total direct fossil energy input with the energy input as human labour. But with regard to human labour, problems arise in assessing its energy 
Table 1. Direct use of fossil energy in Dutch agriculture (in $10^{\text {t2 }} \mathrm{kcal} /$ year).

\begin{tabular}{lc}
\hline Heating greenhouses & 15.3 \\
Horticultural tractors & 0.2 \\
Heating barns, etc. & 0.5 \\
Agricultural tractors & 2.4 \\
Self-propelled machinery & 0.07 \\
Electricity at farm & 0.8 \\
Electricity, polder installations & 0.09 \\
Oil, polder installations & - \\
& \\
Total & 19.4 \\
\hline
\end{tabular}

cost. Since man in the western world uses about $3000 \mathrm{kcal} / \mathrm{day}$ in food, arbitrarily this amount of energy is taken as the best estimate of energy cost of human labour. Alternatively, only the input of energy on the farm can be considered or it can be taken into account that a human being needs more than only food to be able to work. Based on food cost only, the energy input of human labour is about $0.4 \times 10^{12} \mathrm{kcal} / \mathrm{year}$. This shows the minor importance of human labour as an energy source.

It is noted that only a relatively small amount of energy is used in drainage of the 'polders', a task formely performed by the many picturesque windmills. If all the energy should be produced by this source, the windmill certainly would be a nuisance in the landscape.

\section{The indirect use of fossil energy}

Apart from the direct energy consumption there is a considerable indirect energy consumption in the form of fertilizers, herbicides, tractors, buildings, fuel and so on. The amounts involved are considerable. For instance, according to the Tennessee Valley Authority as quoted by Heichel (1973) the energy required in producing $1 \mathrm{~kg}$ of $\mathrm{N}$ as $\mathrm{NH}_{4} \mathrm{NO}_{3}, 1 \mathrm{~kg}$ of $\mathrm{P}_{2} \mathrm{O}_{5}$ as triple superphosphate and $1 \mathrm{~kg} \mathrm{~K} .2 \mathrm{O}$ are 6490,8070 and $1100 \mathrm{kcal}$, respectively. With the fertilizer consumption figures in 1965 this leads to a total energy consumption in this form of $3.7 \times 10^{12} \mathrm{kcal} /$ year or practically as much as the direct energy use in the arable and animal husbandry. However, according to Pimentel et al. (1973) the energy cost of nitrogen production is about three times as much. At the Agricultural University in Wageningen the cost of nitrogen fertilizer production even has been quoted to amount to $30000 \mathrm{kcal} / \mathrm{kg} \mathrm{N}$.

The energy use for the production of a tractor, for instance, may be obtained by analysing in detail the production process, in separate steps. A tractor is depreciated in about 15 years, and a tractor factory produces many tractors during its life-time. The energy cost of building a tractor factory and in any case the energy cost of building the machinery required in building tractor factories, may already contribute little to the indirect energy cost of the farm operation.

Pimentel et al. (1973) followed this line to calculate the indirect cost of maize production in the USA. Their data are summarized in Table 2, together with the direct energy cost, the labour energy cost and the caloric value of the seed yield of corn. Inspection of the data shows that the indirect energy use is slightly more than the direct energy use, a figure which is confirmed by calculations of Borgstrom (1973). However, a 
Input coefficients

\begin{tabular}{lll}
\hline from/to $\rightarrow$ & Agriculture & Industries \\
$\checkmark$ & & \\
Agriculture & 0.12 & 0.81 \\
Industries & 0.017 & 0.51 \\
\hline
\end{tabular}

First iteration indirect energy (in $10^{12} \mathrm{kcal} /$ year)

\begin{tabular}{lll}
\hline from/to $\rightarrow$ & Agriculture & Industries \\
Agriculture & $0.12 \times 53$ & $0.81 \times 53$ \\
Industries & $0.017 \times 1455$ & $0.51 \times 1455$ \\
2 & 31 & 784 \\
\hline
\end{tabular}

Direct use of energy (in $10^{12} \mathrm{kcal} / \mathrm{year}$ )

\begin{tabular}{ll}
\hline Agriculture & Industries \\
53 & 1455 \\
\hline
\end{tabular}

Indirect use of energy (in $10^{12} \mathrm{kcal} / \mathrm{year}$ )

\begin{tabular}{lcc}
\hline $\begin{array}{l}\text { Iteration } \\
\text { number }\end{array}$ & Agriculture & Industries \\
1 & & \\
2 & 31 & 784 \\
3 & 17 & 425 \\
4 & 9 & 230 \\
5 & 4 & 126 \\
6 & 3 & 67 \\
5 & 1 & 36 \\
\hline
\end{tabular}

Flow of energy to consumption sector (in $10^{12} \mathrm{kcal} / \mathrm{year}$ )

\begin{tabular}{llcl}
\hline & Direct & Indirect & To consumption sector \\
Agriculture & 53 & 65 & $0.07 \times(53+65)=9$ \\
Industries & 1455 & 1668 & $0.473 \times(1455+1688)=1477$ \\
Total & 1508 & 1733 & 1486 \\
\hline
\end{tabular}

Fig. 2. An illustration of the use of input-output analysis for computing the indirect energy use in a twosector economy.

detailed analysis also extended to quoted literature reveals that the data at best are approximations.

The energy cost of the many production processes occurring in modern society are still insufficiently known. Moreover, iterative calculation processes are needed, because some industries require their own output as input. For instance, the energy cost of rubber production includes the costs of making the rubber tires used on the rolling stock in the plantation.

The indirect energy cost can be calculated by an iterative process when the inputoutput analyses of economics are used, as introduced by Leontief (1966). This is illustrated in Fig. 2 with data for a two-sector economy: the agricultural and the industrial sector. The direct energy use in these sectors is $53 \times 10^{12}$ and $1455 \times 10^{12} \mathrm{kcal} /$ year, respectively. In the agricultural sector 0.12 of the agricultural produce is used internally and 0.81 is transferred to the industrial sector for further use and processing. Only a fraction of 0.07 is directly used in the consumption sector. On the other hand 0.017 of the produce of the industrial sector is transferred to the agricultural sector and 0.51 is used internally, leaving a fraction of 0.473 for the consumption sector. The first iteration leads to the conclusion that $31 \times 10^{12} \mathrm{kcal} /$ year are indirectly used in the agricultural 
sector and $784 \times 10^{12} \mathrm{kcal} /$ year in the industrial sector. These amounts should be redistributed again by a second iteration, a third and so on. The result of 6 iterations are given. Of course, the process gains in accuracy with more sectors. In this way the requirements of an ideal input-output analysis are more and more met, since in this analysis the products of a sector are assumed to be homogeneous of composition.

The total of direct and indirect energy used in the two production sectors exceeds the amount of energy directly available (Fig. 2). This is due to the fact that in every sector the total flow of energy is counted. When only the flow of energy to the consumption sector is counted, the total amounts to $1486 \times 10^{12} \mathrm{kcal}$. A figure which differs slightly from the original $1508 \times 10^{12} \mathrm{kcal}$. This difference vanishes by increasing the number of iterations.

Sugiyama \& Shimazu (1972) provided input-output data for the Japanese economy, distinguishing 12 economic sectors. They quote the energy, water and land use of each sector, and take into account the imports and exports, and so their data can be used in a more detailed analysis.

The result of this analysis is presented in Table 3. The ratio between direct and total energy use of the various sectors is considerably different. As expected, tertiairy industries use most energy in the indirect form and electrical power plants most in direct form. The direct energy use in the iron and steel manufacturing sector is surprisingly small, but this is due to the great internal use of the produce in this sector.

The flow of energy to the consumption sector through agriculture is only $12 \times 10^{12}$ $\mathrm{kcal} /$ year (Table 3). However, it seems fair to include also the figure of the food manufacturing sector, and then the figure amounts to $189 \times 10^{12} \mathrm{kcal} /$ year or $12.5 \%$ of the total.

Table 3 shows that in Japanese agriculture about 2 times more energy is used indirectly than directly. This figure will be used for Dutch conditions. The only alternative should be to analyse the Dutch economy and the Dutch production processes in much

Table 2. Energy use per acre (0.4 ha) in 1964 for maize production in $10^{3} \mathrm{kcal} /$ year (Pimentel et al., 1973).

\begin{tabular}{lr}
\hline Labour & 6 \\
Machinery & 420 \\
Gasollne & 761 \\
Nitrogen $^{1}$ & 487 \\
Phosphorus & 27 \\
Potassium & 68 \\
Seeds for planting & 30 \\
Irrigation & 34 \\
Insecticides & 11 \\
Herbicides & 4 \\
Drying & 120 \\
Electricity & 203 \\
Transportation & 70 \\
& \\
Total inputs & 2242 \\
Maize yield (output) & 6854 \\
\hline
\end{tabular}

$118480 \mathrm{kcal} / \mathrm{kg} \mathrm{N}$. 
Table 3. Direct and total energy use per sector in Japan (in $10^{12} \mathrm{kcal} /$ year).

\begin{tabular}{lrrrr}
\hline Production sector & \multicolumn{2}{l}{ Input } & & \multicolumn{2}{c}{ To consumption } \\
& direct & total & dir./tot. & \\
\cline { 2 - 4 } & & & & \\
Food & 53 & 155 & 0.34 & 12 \\
Oil refining & 104 & 136 & 0.76 & 8 \\
Electricity & 331 & 358 & 0.92 & 94 \\
Iron and steel & 92 & 524 & 0.17 & 32 \\
Chemical & 262 & 401 & 0.65 & 62 \\
Paper and textile & 91 & 367 & 0.24 & 112 \\
Machinery & 19 & 355 & 0.05 & 198 \\
Food manufacturing & 31 & 221 & 0.14 & 177 \\
Transport & 289 & 380 & 0.76 & 170 \\
Other primary and secondary & 138 & 578 & 0.23 & 117 \\
Other tertiary & 98 & 689 & 0.14 & 516 \\
Total & & & & \\
& 1508 & & & 1508 \\
\hline
\end{tabular}

more detail with respect to their energy use. This is worth the trouble only after a better specification of research goals and methods.

It should be realized then that the technical method and input-output method of computing the indirect energy cost are complementary. The same result is approached but from different sides, and both methods require an exploding effort to achieve accuracy. The input-output method needs a large number of production sectors to obtain sufficient homogeneity within each sector and the technical method requires the analysis of long chains of production processes. Both methods are combined by using the result of the economic input-output method as an input in the technical method, so that only a limited number of production processes have to be analysed.

\section{The three agricultural sectors}

The balance sheet for the primary production sector, the animal production sector and the horticultural sector are given in Table 4.

The direct energy cost of primary production on arable land and graslands is 2.7 $\times 10^{12} \mathrm{kcal} /$ year. Taking the Japenese ratio for granted, the indirect cost is $5.2 \times 10^{12}$ $\mathrm{kcal} / \mathrm{ha}$. The greater part of the indirect cost is for fertilizer production, leaving only $1.5 \times 10^{12} \mathrm{kcal} / \mathrm{ha}$ for machinery, buildings and so on. Although no hard data are available, this may be too low an estimate, but if the latter figure is twice as high this will not markedly affect the general picture. The labour cost and the cost for seeds are negligible in terms of energy.

On the other side are the yields of the arable land, mainly small grains, potatoes, sugarbeets, the straw and tops of these crops and the yield of grassland and foddercrops. The total amounts to $70 \times 10^{12} \mathrm{kcal} /$ year. Hence the total yield of primary production in the Netherlands is nearly 9 times as large as the energy cost.

The balance sheet of the secondary production is completely different. By far the largest energy cost is formed by the fodder products (Anon., 1966a). The input of fossil fuel for direct and indirect use are negligible in comparison.

This indirect use of energy is again based on the Japanese date and therefore very 
Table 4. Energy balances of the three agricultural sectors (in $10^{12} \mathrm{kcal} / \mathrm{year}$ ).

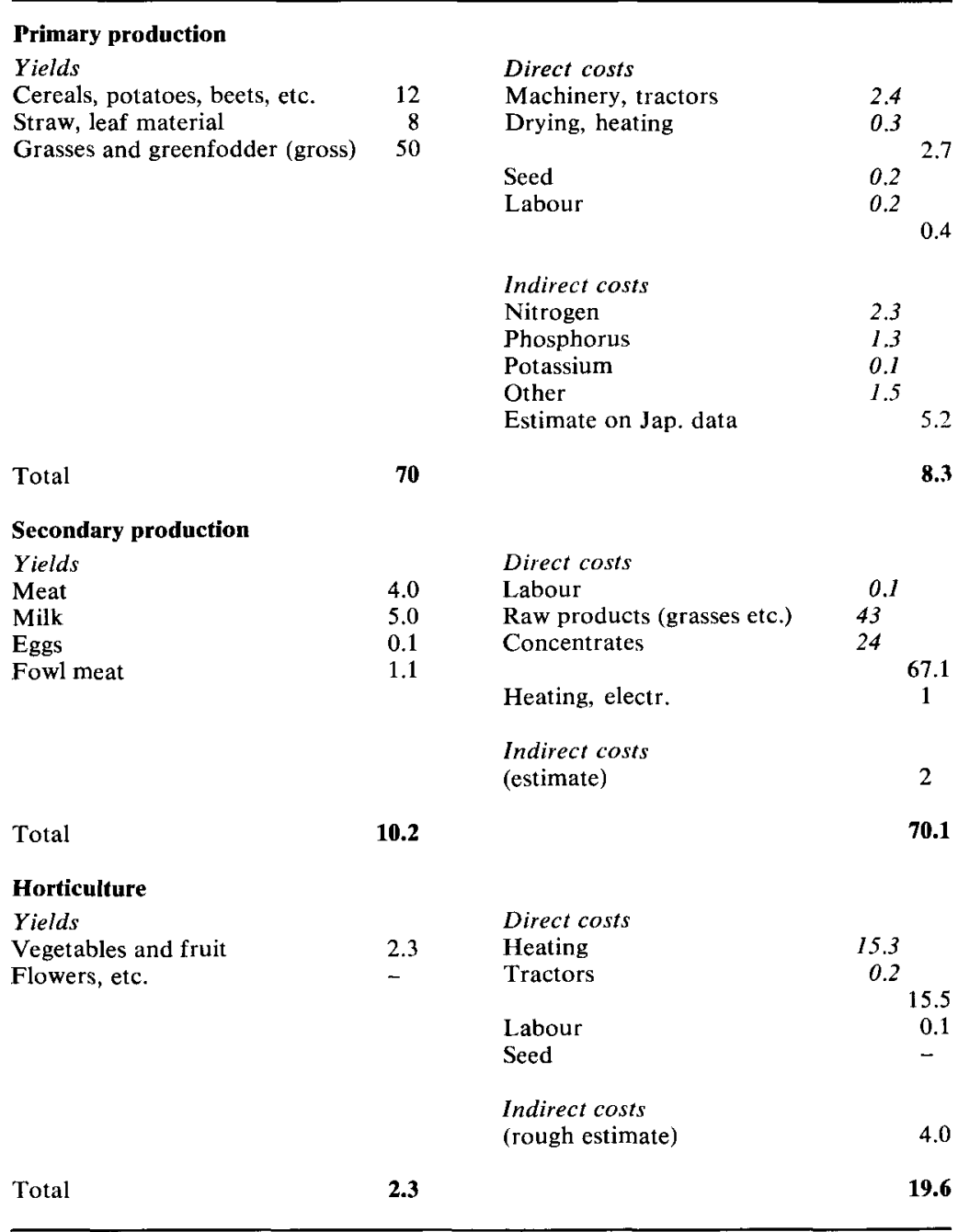

approximate. It may be worthwhile to consider in more detail the energy cost of the transport of imported fodder.

As mentioned, the conversion efficiency in animal production is low and the energy output is about $1 / 7$ th of the input. However, it should be noted that grass is unfit for human consumption and the output is of very high nutritive value. The presence of a secondary production sector proves that the conversion is economically feasable in the present market situation.

The economic feasability holds also for horticulture, but the output of energy is extremely small compared with the input. This sector will undoubtedly suffer the most from 
increasing prices of fossil fuel - probably not by competition with products from regions with a more favourable climate (after all fuel costs of transport by road and air are also impressive), but rather by competition with horticulture in the open and in unheated greenhouses.

The indirect fuel costs of horticulture are very roughly estimated at $4 \times 10^{12} \mathrm{kcal} /$ year, based on the size of the labour force and a rough estimate of material input. The Japanese data on the ratio between direct and indirect energy costs for agriculture as a whole, of course, do not hold for this sector.

Only the energy balance of the primary production shows a net return. Therefore, in the next section the energy relations within the primary production sector are discussed in more detail.

\section{Farming in the southwestern clay district at present and around 1800}

The energy relations on two farms in the southwestern clay district of the Netherlands have been analysed too. The balance sheet of a present-day arable farm of 40 hectares is given in Table 5.

The main cost items are fuel for propulsion of machinery and indirect energy costs such as fertilizers, especially nitrogen and phosphate. The cost of biocides is small, especially if it is taken into account that their use reduces the energy-intensive and labour-intensive weeding operations. Some of them even contribute considerably to yield. For instance Spiertz (1973) found that fungicides increased wheat yields with $14-42 \%$. As far as energy efficiency is concerned, use of biocides should be propagated. Of course, this is without saying anything about their potential danger in modern farming.

In total the balance shows a net return. However, one should be careful. While in the process one form of energy is gained, another is used without being replaced.

The yield of this farm, when recalculated in terms of nitrogen, amounts to $100 \mathrm{~kg} /$ ha. This is about equal to the nitrogen input in the form of fertilizer. If there is an equi-

Table 5. Energy balance of an arable farm of 40 ha in 1965 , southwestern clay district (in $10^{6} \mathrm{kcal} / \mathrm{year}$ ).

\begin{tabular}{|c|c|c|c|}
\hline Yields & & Costs & \\
\hline Wheat & & Labour & 2.5 \\
\hline (11.6 ha, $4600 \mathrm{~kg} / \mathrm{ha})$ & 207 & Seed & 12 \\
\hline Barley & & Fuel & 61 \\
\hline (4.8 ha, $4000 \mathrm{~kg} / \mathrm{ha})$ & 74 & Tractors, buildings, etc. & 30 \\
\hline Legumes & & Nitrogen $(107 \mathrm{~kg} / \mathrm{ha})$ & 28 \\
\hline ( $3.6 \mathrm{ha}, 3000 \mathrm{~kg} / \mathrm{ha})$ & 42 & Phosphorus $(82 \mathrm{~kg} / \mathrm{ha})$ & 26 \\
\hline Potatoes & & Potassium $(47 \mathrm{~kg} / \mathrm{ha})$ & 2 \\
\hline $\begin{array}{l}(5.6 \mathrm{ha}, 34300 \mathrm{~kg} / \mathrm{ha}) \\
\text { Sugar-beets }\end{array}$ & 186 & Biocides & 2 \\
\hline $\begin{array}{l}(6.8 \mathrm{ha}, 45000 \mathrm{~kg} / \mathrm{ha}) \\
\text { Commercial crops }\end{array}$ & 165 & & 163.5 \\
\hline$(7.6 \mathrm{ha}, 4000 \mathrm{~kg} / \mathrm{ha})$ & 118 & & \\
\hline \multirow[t]{2}{*}{ Straw, etc. } & 350 & Net return & 978 \\
\hline & 1142 & & 1142 \\
\hline
\end{tabular}


librium, the unavoidable losses by leaching and denitrification are set off by the supply through rain, and fixation of nitrogen by Rhizobium and free-living bacteria.

It should be noted that the energy production in the form of nearwaste products (straw, etc.) is about twice as large as the fossil energy consumption in direct or indirect form. This might open the possibility for farming systems that supply their own energy. However, if these near waste products are used to provide all energy needs it should be converted to fuel with an efficiency of at least $50 \%$ which may be achieved through fermentative methane production. However, it seems unlikely that energy gained in such a way can be made available for the production of fertilizers or biocides and without these the maintenance of the system is impossible.

Is it at all feasable to maintain high yields and to reduce at the same time the fossil energy input? Probably, it is possible to save temporarily on phosphates and also to reduce soil management operations by the use of more herbicides (Bakermans \& de Wit, 1970). It is also possible to save nitrogen by using more legumenous crops. However, it should be taken into account that the bacterial process of nitrogen fixation requires similar amounts of energy as the industrial process, but in the form of photosynthetic products. Fuel may be saved by using horses, but this increases the labour requirement considerably and decreases net output of primary products.

Table 6. Energy balance of an arable farm of 55 ha about 1800 , southwestern clay district (in $10^{6} \mathrm{kcal} /$ year).

\begin{tabular}{|c|c|c|c|}
\hline Yields & & Costs & \\
\hline Rye & & Labour & 10 \\
\hline$(0.5 \mathrm{ha}, 1800 \mathrm{~kg} / \mathrm{ha})$ & 3.5 & Seed & 20 \\
\hline Oats & & Implements, & \\
\hline (2.5 ha, $2400 \mathrm{~kg} / \mathrm{ha})$ & 23.5 & Buildings & \\
\hline Barley & & From own farm for & \\
\hline ( $3.0 \mathrm{ha}, 2400 \mathrm{~kg} / \mathrm{ha})$ & 27.9 & $\begin{array}{l}26 \text { GVE (animal units) } \\
\text { including }\end{array}$ & \\
\hline$(9.0 \mathrm{ha}, 2000 \mathrm{~kg} / \mathrm{ha})$ & 69.7 & 8 full-grown horses & \\
\hline Peas, etc. & & Clover and grasses & 292 \\
\hline$(1.0 \mathrm{ha}, 2200 \mathrm{~kg} / \mathrm{ha})$ & 8.5 & Oats and beans & \\
\hline Beans & & for horses during & \\
\hline$(3.0 \mathrm{ha}, 2000 \mathrm{~kg} / \mathrm{ha})$ & 23.2 & hard labour & \\
\hline Cole seed & & Milk & \\
\hline$(1.5 \mathrm{ha}, 1800 \mathrm{~kg} / \mathrm{ha})$ & 10.4 & Straw & 156 \\
\hline $\begin{array}{l}\text { Potatoes } \\
(1.0 \mathrm{ha}, 10000 \mathrm{~kg} / \mathrm{ha})\end{array}$ & 9.0 & & 487 \\
\hline Flax (seed and straw) & & & \\
\hline $\begin{array}{l}(3.5 \mathrm{ha}, 550+2800 \mathrm{~kg} / \mathrm{ha}) \\
\text { Clover }\end{array}$ & 45.4 & & \\
\hline$(8.0 \mathrm{ha}, 3000 \mathrm{~kg} / \mathrm{ha})$ & 89.8 & & \\
\hline $\begin{array}{l}\text { Grasses and green fodder } \\
\text { (18.0 ha, } 3000 \mathrm{~kg} / \mathrm{ha}) \\
\text { Fallow } \\
(4.0 \mathrm{ha})\end{array}$ & 201.9 & & \\
\hline Straw & 156.0 & & \\
\hline Milk, $8500 \mathrm{~kg}$ & 5.9 & & \\
\hline \multirow[t]{2}{*}{ Meat } & 7.4 & Net return & 195 \\
\hline & 682 & & 682 \\
\hline
\end{tabular}


Based on a study of Baars (1973) the energy relations of a farm around 1800 in the same district are considered. This was a farm of 55 hectares; its balance sheet is given in Table 6. Less than half the surface of this farm was used to grow marketable products. The remaining part was mainly used for growing cattle and horse food and nearly $10 \%$ of the surface was fallowed, mainly for weed control. The cattle and horses were a source of manure and power and produced some milk and meat as a kind of by-product. Nearly $2 / 3$ of the primary production was used for this purpose. Apart from that a considerable amount of products were used for maintaining the labour force of about 10 persons and for seed.

The input of energy from outside the farm was negligible. It concerned mainly implements and neither the amount nor the quality of them was very impressive (Dewez, 1958). The net energy production of this farm was $195 \times 10^{6} \mathrm{kcal} / \mathrm{ha}$, an impressive amount. However, two factors should be taken into account. The farm was situated on excellent soil and yields were often lower due to hazards of all kind. This is also reflected by the large number of different crops on the farm.

Recalculated in terms of nitrogen, this net yield amounted to about $15 \mathrm{~kg} \mathrm{~N} / \mathrm{ha}$. This amount is to be expected from rain and by free-living bacteria and by a limited growth of legumenous crops.

This farm was self-supporting in terms of energy, and used renewable resources only. The present-day farm is in a much worse position as the production is dependent on external energy sources. However, in respect of food availability the saving of fossil energy by introducing farming methods of the 19th century opens poor prospects, because the total production of food will decrease with a factor of about four.

\section{Final remarks}

This paper illustrates to what extent agriculture in the Netherlands is dependent on fossil energy input. An input of fossil energy which can hardly be reduced at present without yield decrease or a considerable increase in labour input.

Although figures for indirect use of energy are given it is stressed again that they are approximate at best and that good figures can be obtained only by combining the technical and economic approach. Figures of this kind are a necessary basis for achieving minimum fossil energy use.

It may be a challenge to develop production systems with near potential production, but with a minimum input of fossil energy in its direct and indirect form. Such systems certainly are important for developing countries, since the green revolution type of agriculture is expensive due to high energy inputs (Pimentel et al., 1973), certainly with oil prices increasing so drastically.

\section{References}

Anonymous, 1966a. Het veevoergebruik in de periode 1 juli 1965-30 juni 1966. Ministerie van Landbouw en Visserij, Den Haag.

Anonymous, 1966b. Energienota; Rapport op de belastingheffing op energie. Ministerie van Economische Zaken, Den Haag.

Anonymous, 1971. Food balance sheets 1964-1965. FAO, Rome.

Baars, C., 1973. De geschiedenis van de landbouw in de Beyerlanden. Pudoc, Wageningen. 
Bakermans, W. A. P. \& C. T. de Wit, 1970. Crop husbandry on naturally compacted soils. Neth. J. agric. Sci. 18: 225-246.

Borgstrom, G., 1973. Food, feed and energy. Ambio 2: 214-219.

Dewez, W. J., 1958: De landbouw in Brabants westhoek in het midden van de $18 \mathrm{e}$ eeuw. Agron. hist. Bijdr. 4: 1-65.

Heichel, G. H., 1973. Comparative efficiency of energy use in crop production. Bull. Conn. agric. Exp. $\operatorname{Sin} 739$.

Lange, J. M., 1973. Onderhoudskosten en gebruik landbouwtrekkers. I.L.R. Rapport 224, Wageningen.

Leontief, W. 1966. Input-output economics. New York.

Pimentel, D., L. E. Hurd, A. C. Bellotti, M. J. Forster, I. N. Oka, O. D. Sholes \& R. J. Whitman, 1973. Food production and the energy crisis. Science 182; $443-449$.

Spiertz, J. H. J., 1973. Effects of successive applications of maneb and benomyl on growth and yield of five wheat varieties of different heights. Neth. J. agric. Sci. 21: 282-296.

Sugiyama, K. \& Y. Shimazu, 1972. Some problems in economy oriented environmentology. I. J. Earth Sci. Nagoya Univ. 20: 1-29.

Wit, C. T. de, 1972. Food production: past, present and future. Stikstof 15: 68-80.

Wit, C. T. de \& A. Th. J. Nooy, 1973. Over eten en over leven. Diesrede Landbouwhogeschool, Wageningen. 